\title{
Trials as Messages of Justice: What Should Be Expected of International Criminal Courts?
}

\section{Tim Meijers and Marlies Glasius}

I

n January 2016, Fatou Bensouda, the prosecutor of the International Criminal Court (ICC), announced the opening of the court's tenth and most recent country investigation, into alleged crimes perpetrated in Georgia during the brief 2008 Russo-Georgian War. The crimes to be investigated may include murder, destroying enemy property, attacks on a peacekeeping mission, deportation, and ethnic persecution. Bensouda intends to make arrests, put suspects on trial, and, if they are found guilty, have them convicted and punished. Meanwhile, even as Bensouda prepared this newest case, the ICC was still prosecuting a suspect in the court's very first investigation, from 2004, against Dominic Ongwen, a commander of the Ugandan Lord's Resistance Army. These two cases can thus serve as bookends to the ICC's short history, illustrating the long arc between initial investigations and eventual trials, and highlighting the complexity and contingency of international criminal justice.

In this article we ask what-if anything — is the point of all this effort, and what can and should we expect from international criminal courts? After more than a decade of work, the accomplishments of the International Criminal Court are highly contested. The court has been accused of bias, of spoiling peace negotiations, of hindering successful transitions to democracy, and of being disconnected from the needs of conflict-affected populations. ${ }^{1}$ We will not address these controversies here. Instead we focus on a more theoretical question: How can international trial and punishment constitute a suitable response to episodes of mass violence?

The Statute of the ICC itself provides several indications. Its Preamble proclaims that "the most serious crimes of concern to the international community as a whole must not go unpunished," that it is "determined to put an end to

Ethics \& International Affairs, 30, no. 4 (2016), pp. 429-447.

(C) 2016 Carnegie Council for Ethics in International Affairs

doi:10.1017/So89267941600040X 
impunity for the perpetrators of these crimes and thus to contribute to the prevention of such crimes," and it is "resolved to guarantee lasting respect for the enforcement of international justice" through the establishment of the court. ${ }^{2}$ This invocation alludes to the two classic approaches to punishment-retribution and deterrence-and perhaps to a third, hybrid approach known as "legal expressivism," which we discuss in detail below.

In this article we argue that the two traditional approaches to international justice have serious limitations that can only be overcome by taking the expressivist view. We also explain why and how international criminal trials are supposed to contribute to the successful transition of a conflict-ridden society to a secure one governed by the rule of law. Contrary to existing defenses of expressivism, we focus on the value of trials in and of themselves, rather than the punishment that may follow them. Finally, acknowledging the limited success of international criminal justice so far in terms of fulfilling its expressivist potential, we diagnose the main obstacles to expressivist messaging in the contemporary practice of international criminal justice.

\section{Why Traditional Views Fall Short}

Criminal trials are closely connected to punishment, and hence the purpose and justification of trials tends to be associated with the purpose and justification of punishment. Why is it justified to inflict harsh treatment, considered morally wrong and illegal in any other circumstance, upon convicted criminals? A purely consequentialist view about international criminal courts is that they should aim to achieve-and are worthwhile insofar as they have-beneficial consequences or, more specifically, deterrent effects: that is, they will prevent the commission of future crimes. ${ }^{3}$ The potential of criminal trials to achieve this deterrent effect, however, remains dubious. Specific deterrence tends to be practically irrelevant: the chance that convicted war criminals will be in a position to commit the same or a similar crime is almost nil. General deterrence, on the other hand, aims to convey a message to all potential violators of the law: "Do not do X or you will suffer punishment Y." We should not expect too much of this either, since the chances of getting caught for these types of crimes are very low; and when caught, the options for punishment sometimes simply do not (and cannot) match the circumstances: time in jail might be a deterrent for burglars (life outside prison has its advantages), but for potential defendants at international courts the choice 
might be between ending up in a cell in The Hague and a violent death at the hands of their opponents. ${ }^{4}$

A second challenge for deterrence is its reliance upon a rational actor view: criminals are assumed to be calculating the utility of their actions and pursuing their rational interests. This is an oversimplification even in ordinary circumstances, but in the case of war crimes or crimes against humanity, where crimes are collective and the normative order is sometimes overturned, it becomes particularly implausible. ${ }^{5}$ For example, during the wars of dissolution of Yugoslavia, some Serbs, Croats, and/or Bosniaks may have sincerely believed that they were doing the right thing (perhaps based on false beliefs and false information) when acting criminally, and may have been willing to die for their cause. A higher likelihood of being captured or a more severe punishment would have changed little. ${ }^{6}$ Moreover, because war crimes are often the product of the cooperation between hundreds if not thousands of people, who exactly are international courts aiming to deter? Members of groups that perpetrate war crimes or crimes against humanity are more likely to be influenced by pressure from peers or superiors at that time and place than by mild and nebulous judicial threats. ${ }^{7}$ For all these reasons, we think that deterrence alone is neither a plausible nor a desirable theory to provide the primary rationale for the practice of international criminal justice.

The other traditional view about the purpose of international criminal courts is retribution: that courts should aim to-and are worthwhile insofar as theyadminister punishment as retribution against those who have committed crimes. This is a backward looking view: punishment may or should be inflicted on the criminal because of what he or she did; it is justified, desirable, or required as a response to wrongdoing. ${ }^{8}$ Yet retributive theories also have several elements that render them especially problematic when applied to international criminal courts. The first is proportionality: the punishment has to match the crime. But any punishment for someone responsible for the destruction of hundreds or thousands of lives will be "totally inadequate" from the perspective of retribution. Further, increasing the severity of punishment is even less an option for retributivists than for consequentialists, given that for most retributivists cruel and degrading punishments clash with their deontological commitments (for example, respect for human dignity ${ }^{10}$ and human rights). There is some discussion among retributivists about whether capital punishment is compatible with these commitments, ${ }^{11}$ but they certainly render cruel and degrading punishment impermissible. The second problematic element is that, in circumstances where crimes 
are collective and the normative order has been overturned, mens rea can be doubted: if the behavior now considered criminal was considered normative at the time and place when it occurred, the idea of retribution becomes more complicated. Lastly, retribution solely for retribution's sake could imply ignoring collateral implications: for example, criminal proceedings that would lead to a longer, more violent conflict; disrupt peace negations; and/or damage relations within society for decades.

As in the case of deterrence, we do not aim to show that the retributivist theory has no merit, but the concerns outlined above do demonstrate that, like consequentialism, retribution is neither a plausible nor a desirable theory to provide the primary rationale for international criminal justice.

\section{LEgAL EXPRESSIVISM}

\section{Empirical Expressivism}

The things we do and say, and the way we do and say them, convey messages to others: they convey our attitude, our plans, our needs and desires, and our beliefs to the people around us. Likewise, what institutions "say" and "do" also convey messages. As Cass Sunstein points out, this is also the case for the law, noting that "there can be no doubt that law, like action in general, has an expressive function." ${ }^{2}$ This observation forms the basis of a family of theories known as "legal expressivism." ${ }^{13}$ These theories rely on the idea that laws and legal institutions have the potential to send messages. Such messages can be either intentional or unintentional: sometimes our actions reveal attitudes that we did not mean to reveal, and sometimes our audiences misinterpret what we are doing. Additionally, most expressivists believe in a transformative hypothesis: laws and legal institutions have the potential to alter people's behavior and attitudes through messaging. Consider Patricia Funk's research on the effect of symbolic fines for not voting in elections. Funk has found that the fines have a significant impact on voter turnout. Because the fines are symbolic (very small) one can assume it is not the actual cost of the fine that is encouraging voting but rather, she argues, "the legal statement that citizens should vote apparently caused certain citizens to follow." ${ }^{14}$ Expressivism can take the form of an empirically testable hypothesis about the potential of institutions to send messages to a public, with a measurable effect on its behavior or beliefs. 


\section{Normative Expressivism}

We are not only interested in empirical expressivism but also in asking an additional question: How should institutions use this potential to play a transformative role? Normative expressivists defend two additional claims both of a normative nature. First, there is the Content Claim: the content of the message as expressed to the public determines whether an institution functions in the right way. An example of such a claim would be saying that the law should express equal respect to people of different groups. If it does not do so, the institution fails to send the right kind of messages. The second claim is a normative version of the transformative claim. As Sunstein points out, expressivists' "principal aim is to defend laws that attempt to alter norms, rather than laws that merely speak." ${ }^{15}$ Thus, normative expressivists argue for what we will call the Expressive Effect Claim: one goal of the institution is to send a message to a public in order to realize a given result. An example would be a symbolic fine for double parking: the fine sends a message to the offender that double-parking is wrong, thus educating her as to how to park her car in the future.

Both claims depend on the accuracy of empirical expressivism. We cannot require institutions to send messages (or create institutions with the intention to send these messages) that they are unable to send: ought implies can. An obligation to express messages with a transformative potential presupposes that this can be done.

On the expressivist view, the goal of trial and punishment is the expression of messages, often about moral or legal wrongdoing. Courts can express these messages to several different audiences (sometimes simultaneously), using various means:

(a) To the criminal (that this action was wrong and should not have happened), where the goal is to educate, reform, or give an opportunity for repentance. ${ }^{16}$

(b) To the victims (that this action was wrong and should not have happened to you), where the goal is to satisfy calls for accountability, recognition, and so on. ${ }^{17}$

(c) To the society or societies (that these kinds of actions are wrong), where the goal is to educate or convince the general public not to behave similarly. ${ }^{18}$

The appeal of this school of thought lies in its hybrid nature, as it takes elements both from retributivism and consequentialism. It is backward-looking in the way retributivism is: trial and punishment are an appropriate response because-and 
insofar as-they respond to the crime committed. Backward considerations clearly matter because wrong acts call for disapproval, for the expression of moral blame, and for calling to account. Trial and punishment, as an expression of blame and disapproval, are intimately linked to the crime. The crime calls for condemnation, and expressivism fulfills this need. But the reason condemnation is required lies in the kind of consequences trial and punishment can bring about: education, recognition, and prevention.

In this way, expressivism is also forward-looking. The reason why trial and punishment are intimately linked to the crime is that they can help educate the criminal, acknowledge the wrong to the victim, and reaffirm commitment to the law to the general public. Unlike consequentialism, expressivism can help explain why a criminal should be punished based on (intuitively plausible) backward-looking considerations: the act stands in need of disapproval. The need for punishment does not merely arise as a means to an end. Unlike retributivism, it does not (implausibly) leave all forward-looking considerations completely out of the picture.

\section{Expressivism in International Criminal Justice}

International criminal trials are part of a broader set of transitional justice responses that may also include restorative justice measures, truth commissions, compensation and rehabilitation measures, commemorations, and the exclusion or removal of wrongdoers from office. Such measures are not mutually exclusive; on the contrary, they probably work best in combination. It is therefore not necessary to show that international criminal trials are the best possible response. It is, however, necessary to show that they contribute something to transitional justice situations that other measures do not achieve. There is a heated debate as to whether the pursuit of justice, through its transformative intent, actually obstructs the short-term pursuit of peace. We do not intend to contribute to this debate, which neglects the more fundamental question: How are international criminal trials supposed to be a part of a successful transition?

Expressivism offers a hypothesis about the mechanisms behind the putative transformative potential of international criminal courts. Mark Drumbl, for instance, writes that

trials can educate the public through the spectacle of theater-there is, after all, pedagogical value to performance and communicative value to dramaturgy. This 
performance is made all the more weighty by the reality that, coincident with the closing act, comes the infliction of shame, sanction, and stigma upon the antagonists. ${ }^{19}$

For expressivists, sending these messages is the point of the practice of international criminal justice. However, as legal scholars they do not typically look closely at the plausibility of the empirical claim that trials indeed have this effect. ${ }^{20} \mathrm{We}$ suggest that the claim should be reformulated as a prescriptive one. International criminal courts should aim to realize expressivist potential, and they are worthwhile if-and insofar as-they succeed. We do not claim that all current international criminal courts are transforming societies through trials, but rather that they should aim to do so.

\section{Shifting the Focus to the Trial}

Surprisingly, expressivists, including those like Drumbl ${ }^{21}$ and Robert Sloane who have sought to apply the theory to the international context, have focused almost exclusively on punishment. But punishment is not the core of the expressive capacity of international criminal justice. The practice of international criminal justice must include both trial and punishment, and the former is key.

Consider the several expressive functions of punishment that Joel Feinberg ${ }^{22}$ identifies: disavowal of the crime (it should not have happened); nonacquiescence (we were not a part of it); vindication of the law (the law should be honored and we take it seriously); and the absolution of others (it was this person, no one else). All of these appear to be realized by the trial and the verdict in themselves, not by the punishment. ${ }^{23}$ The first crucial message that is ideally expressed in courts is the truth about whether a certain crime has taken place. Through the presentation of evidence by prosecution and defense, certain facts should become undeniable. ${ }^{24}$ Once it has been established that the event has taken place, we can recognize that what was done (no matter by whom) was illegal and wrong. This is already a form of recognition for the victims. It encompasses disavowal of the crime and nonacquiescence: the fact that the trial takes place and the crime is taken seriously already expresses those messages. Even if the guilt of the defendant cannot be proven beyond reasonable doubt, or if she is found guilty but not punished, this remains true. The same goes for vindication of the law. Appealing to and applying the law to this case in a fair way-even if it does not result in punishment, for whatever reason-already shows that the laws are being taken seriously. 
Messaging starts long before the verdict is pronounced and the punishment administered.

Societies that are deeply torn are in great need of messages of disapproval and the apportioning of blame. What is at stake in these societies is the value of the rule of law itself. As Antony Duff notes, "To remain silent in the face of crime would be to betray the values which the law expresses, and to which we are committed." 25 This is much less the case in domestic law. One thief getting away without a trial is no threat to people's understanding that theft is wrong. But international courts dealing with fractured societies, in addition to making claims about the crimes committed, must also aim to send messages about the value of the rule of law.

The damage caused by a crime may go beyond the direct victims or the community affected. As a tossed stone sends ripples through a pond, a massive crime creates concentric circles of ever-lessening impact outward from the direct victims - to the local community, to the broader society or ethnic group, to neighboring states, and so on. Of course, if societies are deeply disrupted, and they often are in the situations where international criminal courts are concerned, any form of punishment may represent only a small step toward repairing what was broken.

However, trials and verdicts alone, without any version of punishment, would not suffice. Trial without punishment could too readily be interpreted as empty rhetoric. Some kind of punishment remains inevitable because of the value that is conventionally attached to it: not punishing a criminal will be understood as not taking the crime seriously. Courts need to speak the language of the community they are trying to transform, and trials are a readily understood format only if they are accompanied by the possibility of punishment. ${ }^{26}$ There could, of course, be more imaginative and culturally appropriate forms of punishment than incarceration, which may enhance the expressive value of punishment.

Unlike some consequentialist theories, expressivism is not vulnerable to the objection that it reduces the defendant to a mere means to an end. It is compatible with a justification for punishment based on responsibility for contributing to the breakdown of society. If trial and punishment are necessary for repair, the cost of the punishment falls on the person who created the need for repair. Expressivism is, then, compatible with weaker forms of retributivism: punishment is not required, but it is permissible, because the criminal has committed the crime.

Does our trial-focused version of expressivism reduce international criminal trials to show trials? This need not be the case, provided that international 
criminal justice recognizes two key constraints that flow from the internal logic of expressivism itself: trials must be fair and punishment must be humane. International criminal courts should aim to realize certain consequences, and to function in a manner that maximizes these consequences within these constraints. Hence, expressivism is compatible with liberal values. Holding someone accountable in an unfair trial undermines the messages the court intends to send.

The limits of permissible punishment arise from similar considerations. But the punishment will send messages too, and should not convey any unacceptable collateral messages (see the Content Claim above). Anthony Skillen rightfully points this out by emphasizing that punishment cannot be in tension with the message it is trying to convey:

Durkheim, like Kant, placed great stress on the significance of different forms of punishment and strongly condemned corporal punishment because it conveyed the opposite of the intended message-stressing sheer physical power at the expense of moral authority. ${ }^{27}$

Certain modes of punishment, apart from sending a message of disapproval, send contradictory (and unacceptable) messages:

What if the punishment form, the medium, is cruel, degrading, corrupting, wasteful, or divisive? What if the actual communication is in direct contradiction with the putative message '(Whack!) Don't hit children smaller than you!'; 'Execute him! We must show the value of human life. ${ }^{28}$

Punishment should not be a mere display of power of one over the other. This is exactly the kind of message criminal courts should counter. Showing brute force rather than reasons and respect for legal norms would, instead of reaffirming the legal (and moral) order, be a continuation of the conflict by other means. The message sent by the punishment itself limits how much and what kind of punishment is permissible. Although enforcement of punishment inevitably comes with the use of power, it must be exercised by a legitimate authority for the right kind of reasons.

The version of expressivism we defend here takes the following form: international criminal courts achieve their aim if-and insofar as-they manage to convey the right kind of messages, especially to societies in transition. The trial is a way to reaffirm legal order, establish truths, recognize the wrongs committed to the victims, and educate the public at large. It is not only a message about the 
crimes but also about the system of justice. It affirms its difference from the moral universe in which the crimes could occur precisely through its meticulous procedures and standards of evidence, and a humane punishment at the end. It is a way to say "no!" to war crimes and crimes against humanity. The message is one of respect for basic human rights and of nonviolent conflict resolution, and an exercise in the rule of law-all key ingredients for the (re)establishment of a well-functioning society.

On this view, the fact that international criminal courts are not "of the community" whose crimes they adjudicate is an advantage over domestic trials, but only under very particular circumstances, namely, when the community itself is shattered and the legal order can no longer be affirmed because it has ceased to exist. In such cases, institutions that are at least partially external to the society are needed. ${ }^{29}$ Establishing when such circumstances exist, and therefore when it is right that the subsidiarity principle should be superseded, is likely to be contentious, as evidenced by the lively academic and policy debate over the ICC Statute's complementarity clauses. ${ }^{30}$ At a more theoretical level, accommodating the role of an outside institution might be a problem for strictly Durkheimian conceptions of criminal law as the expression of a collective conscience. But if we adopt a more dynamic view, international criminal courts can, instead of expressing the values of an existing social order, help to transform these values and contribute to forging a new social order. Helping to transform the values of a society is, however, an ambitious and controversial aim, and accusations of imperialism easily flow from it. Such a mission places high demands on the communicative skills of the courts. Their international character may in principle be a solution to the problem of crimes that tear at the heart of a society, but in practice the lack of sociological legitimacy with local populations has often been a major problem. In our next section we will turn to this and other obstacles to the expressive function (and hence to realizing the purpose) of international criminal justice.

\section{Opportunities and Threats to Expressivist Trials: A FrameWORK FOR ANALYSIS}

In this section we aim to point out some of the main obstacles to the fulfillment of the expressivist potential in international criminal justice to date. We will distinguish between obstacles we believe to be structural and those that agents of the courts could attempt to overcome. Since expressivism relies on communication 
for its success, we use the basic units of analysis employed by communication theorists to provide this framework: the sender, the message, the medium, and the audience.

\section{The Sender}

While we have thus far discussed "international criminal courts" as if they were monolithic actors, each court in fact encompasses multiple senders. Expressivist theories mainly focus on the judges as message-senders, since they are in charge of the verdict and sentencing. But the ICC and other international criminal courts consist of various departments, such as a registry, a witness unit, an office of the prosecutor, and (often more of an afterthought) an outreach unit. Tensions between these units may sometimes lead to ambiguous or contradictory messaging.

Such problems pale in comparison to the fundamental "sender tension" we discern in international criminal trials. Our focus on trial rather than punishment brings into view two fundamentally opposed actors: prosecution and defense. In an ordinary domestic criminal trial, this opposition usually does not interfere with the messages a trial is supposed to send. While the defense will argue either that there is room for reasonable doubt or for extenuating circumstances about the accused, both sides will either tacitly or explicitly agree that theft or assault is illegal, and that the court in question is competent to try and punish cases of pickpocketing, burglary, or actual bodily harm.

Not so in international criminal courts. Defendants and their lawyers frequently attempt to portray their acts as necessary and even heroic in the context of war, and often explicitly challenge the court's jurisdiction, sometimes portraying the court itself as politically motivated. ${ }^{31}$ Hence, the expressivist potential is compromised-although not completely undermined ${ }^{32}$-by the fact that at the heart of the system there is a message-sender whose messaging is likely to be fundamentally at odds with the messages we would expect from most other units of the court, including reaffirming legal order, establishing a particular version of the truth, recognizing the wrong committed to the victim, and educating the public. To what extent the defense follows a strategy of challenging all these messages will of course vary from case to case, but it is safe to assume that the criminal, rather than political, nature of the acts being adjudicated and the legitimacy of the court will continue to be contested for some time to come. One element that exacerbates this tension and that could-even in our non-ideal world-be alleviated is the largely Anglo-American, accusatory character of most international criminal 
trials. A partial solution would be a move to a more inquisitive system, in which judges play a more proactive role vis-à-vis prosecution and defense, which would alleviate this "sender-tension," even though any fair trial will have to leave room for the defense to speak its mind.

\section{The Message}

According to Martti Koskenniemi, because of the fundamental opposition between prosecution and defense sketched above, international criminal courts are caught in a paradox:

To convey an unambiguous historical "truth" to its audience, the trial will have to silence the accused. But in such case, it ends up being a show trial. In order for the trial to be legitimate, the accused must be entitled to speak. But in that case, he will be able to challenge the version of truth represented by the prosecutor and relativise the guilt that is thrust upon him. ${ }^{33}$

We are less deterministic, believing that while the accused is likely to try and challenge the prosecutors and to preemptively undermine the judges' verdict, his success in doing so is by no means a foregone conclusion.

One key variable in this respect is the manner in which other "senders" meet the challenge by the defense. In two high-profile cases that we have investigated, ${ }^{34}$ the prosecution only engaged with the defendant in relation to the charges contained in the indictment, but mostly ignored the suggestion by the defense that the prosecution was biased or that the trial was somehow less than legitimate. If the expressivist justification for international criminal justice is convincing, it follows that the prosecution and the bench should attempt to defend the practice of international criminal justice, and engage with the public outside the courtroom. In order to meet the challenge posed by this worry, they should explain the purpose of what they are doing not just in legalistic but in broader terms, responding to criticism from both the defense and third parties. An example of this comes from the trial of former Liberian president Charles Taylor. On the day of the closing statement for the prosecution, Taylor's lawyer, Courtenay Griffiths, stole the show by challenging the legitimacy of the court, both inside and outside the courtroom, using WikiLeaks cables that revealed an American diplomat had been pushing for a speedy end to the trial. The prosecution ignored the incident and proceeded as planned, but failed to put the real issue, Taylor's alleged war crimes, back into the limelight. ${ }^{35}$ 
Unintended messages are equally important. A key threat is that international criminal trials are almost inevitably selective. A victim may interpret the lack of a trial as a failure to take the crime seriously; and someone who identifies with a particular side in the conflict under adjudication will discern bias if members of one side are on trial, but not the other. How can one justify putting a particular individual on trial rather than the many others who are apparently equally guilty? In fact, there is good reason to do so. Representative trials can serve as a way to manage selectivity without sending the wrong message, but only if the victims and society at large can be convinced that the focus on a particular instantiation of a widespread crime does indeed represent a wider class that is being condemned, rather than a bias of the court. In this respect, the practice of the Yugoslavia Tribunal, ${ }^{36}$ which went out of its way to put representatives of all ethnic groups on trial, may be preferred over the necessarily more pragmatic approach of the ICC, which often ends up prosecuting only suspects from one side in a conflict because they happen to be available for arrest.

Most problematic to the expressivist approach are the messages-usually unintended-that convey that selective justice is not just a matter of capacity but of political constraints or motivation. The Yugoslavia Tribunal's unwillingness to consider the NATO bombings of 1999 and the ICC's inability, to date, to pursue any non-African cases are clear examples of such political constraints. The fate of the current investigation of crimes committed in the 2014 Gaza conflict will be of particular symbolic importance to the ICC in this respect. There is little that courts can do to counter perceptions of bias due to political constraints. Only a court less constrained by real-world political considerations could avoid sending such problematic messages. However, if we are right in arguing that courts can make an important contribution through the messages they send, a further argument may be made: that those actors generating political constraints on international criminal courts (and, by doing so, severely limiting their expressive potential) are wrongfully preventing the courts from doing their job.

\section{The Medium}

The medium for international criminal justice comes in two forms. First, the courtroom itself can be considered as a medium: closed sessions apart, trials are public. While it is possible to attend an entire trial, hardly anyone has the time, means, and stamina to do so. Important moments in a trial draw a full house, but routine trial sessions are poorly attended. ${ }^{37}$ That these trials take a long 
time is inevitable and not to be regretted. Hurrying them along, which would perhaps make them effective as a medium, would undermine the quality of the messaging, compromising precision and accuracy. ${ }^{38}$ An additional problem from the point of view of contributing to the repair of damaged societies is that most trials take place in The Hague, out of reach of the vast majority of members of those societies. Although all international criminal courts nowadays broadcast their trial sessions online, we know very little about how well these sessions are watched by people in affected societies. We can surmise, however, that there are material constraints to good Internet access.

Most people are likely to become aware of international criminal trials in the second, mediated form through radio, television, newspaper, or Internet reports. ${ }^{39}$ Some of these media, in particular donor-supported nonprofit initiatives, have a mandate to fulfill some of the expressivist purposes of conveying truths, recognizing victims, educating the public, and reaffirming the rule of law that we are proposing for the trials themselves. Others, such as professional journalists, will be primarily interested in finding angles they believe will attract their target audiences. Yet another group may be affiliated with particular political factions in society. In the former Yugoslavia, and more recently Kenya, political actors have themselves relayed populist messages about international criminal trials to local audiences. $^{40}$ The interests of the latter two groups may well be at odds with the expressivist aims of international criminal trials. There is an urgent need for social science research on the effects of mediation on the reception of international criminal trials. The nature of mediation may be assumed to be an important variable in the success of expressivist messaging, and we know very little about it.

\section{The Audience}

The final link in the communicative chain is the audience. While there may be multiple audiences for international criminal trials (such as international legal scholars and potential perpetrators of crimes in third countries), our expressivist approach, positing international criminal trials as a form of transitional justice, has identified the population of the conflict-affected area that is being adjudicated as the audience of primary interest. Within this group, we distinguish between society at large, which we describe as "affected" so as to encompass different degrees of culpability and victimhood, and direct victims. Direct victims, as we have described above, require different messaging; their needs refer more to the 
backward-looking aspect of expressivism, whereas messaging to the broader society is more forward-looking.

The first question to be asked about the audience is whether it is indeed an audience, that is, whether it is even aware of the existence of the court and the ongoing trials. The survey work done by Phuong Pham, Patrick Vinck, and others consistently shows that audiences in African societies know very little about the ICC or about ongoing trials. ${ }^{41}$ The first instinct, of course, is to insist that the ICC invest more in outreach. However, while it follows from the expressivist approach that the relative status and budget of the outreach section should be much greater than it is currently, it is also necessary to recognize that structural constraints hamper reception of the courts' messages. In the eastern Democratic Republic of the Congo (DRC), the primary focus of the ICC to date, poverty is so great and physical insecurity remains so high that it is unrealistic to expect most of the population to take much interest in, or even to take very seriously, the messages of the court. Citizens of the DRC are still in a struggle to survive; their general living environment gives the lie to the idea that they are in transition to a rule-bound society.

In other circumstances, the obstacle to expressivism may lie mostly in the legacy of the conflict. When a trial begins its messaging, audiences are far from a tabula rasa. Not only have they lived through the conflict themselves, they have also been exposed to (probably highly polemical) media messages and political propaganda. In divided societies, every news item, and certainly international criminal trials, gets filtered through a lens of ethnic, religious, or other conflict-related bias. While experts disagree on the extent to which the Yugoslavia Tribunal succeeded in relaying expressivist messages, ${ }^{42}$ they all emphasize that the prejudices emanating from ethnic division have been extraordinarily difficult for the tribunal to overcome.

The two main threats to expressivism with regard to audiences, then, are continued circumstances of material and/or physical insecurity and the legacy of division emanating from the conflict, both of which will make it very difficult for expressivist messages to be internalized by their intended audience. The first worry stems from the regrettable fact that information is often inaccessible to poor and often illiterate populations. Difficulties in involving the masses limit the expressive function of a court, but they do not completely undermine it. The social, political, and legal elites of the affected society are much easier to reach as an audience. ${ }^{43}$ Given that elites will inevitably have an important role 
to play in a successful transition, this may already be a nontrivial way in which courts can have a transformative impact. ${ }^{44}$

The second worry is inherent to those cases that involve conflicting parties. Courts can preempt some of the problems that will arise in such scenarios by having a diverse team of prosecutors (in contrast to the Charles Taylor trial, which had mostly American prosecutors ${ }^{45}$ ) or by not being financially dependent on only a few (or one) major donors (in contrast to the Special Court for Sierra Leone, which depended largely on the United States for its funding).

\section{Conclusion}

In this article we have defended an argument about what we can and should expect from the practice of international criminal justice. After arguing that retributivism and consequentialism alone do not provide appealing goals for international courts, we have attempted to provide a plausible alternative account of what these institutions could, and should, aim to realize. Our view is modestly optimistic and ambitious. We see several ways in which international criminal justice could be a worthwhile project: through aiming to contribute to social change by demonstrating what crime was committed; by delineating why it was wrong and illegal; and by exemplifying how such wrongs ought to be adjudicated. We have emphasized the importance of the trial, not just the punishment, as a form of expressive messaging, and insisted on the communicative aspects of the judicial process.

We do not suggest that today's international criminal trials necessarily have these expressive effects. We identify several obstacles to this goal, some of which appear to be a structural feature of international criminal justice. We believe others could partially be overcome. There is a tension at the heart of international criminal justice that facilitates contradictory messages being sent by prosecution and defense. The defense needs to be allowed to speak, but expressivist messaging will only succeed if fundamental challenges to a trial's legitimacy can be parried.

While there is much room for improvement in the prosecution and judges' handling of their communications with the outside world in this respect, the effect of unintended messages sent by the selective nature of the justice remains a concern. There may also be opportunities for and threats to expressive messaging at the level of media reportage on international criminal justice. This is where current scholarship is patchiest, and we suggest that further research should be undertaken. 
Finally, for the audiences who are to receive transformative messages, the main threats are their continued insecurity - which may make messages about reestablishment of the rule of law implausible despite an international criminal court's best efforts-and the legacy of exposure to division, violence, and one-sided political messaging during the conflict. It is beyond the courts' capacities to solve these problems, but we hope to have shown that even with these non-ideal constraints, there are reasons to believe that courts could and should be able to make a difference.

\section{NOTES}

${ }^{1}$ See, for instance, Adam Branch, "Uganda's Civil War and the Politics of ICC Intervention," Ethics \& International Affairs 21, no. 2 (2007), pp. 179-98; Helena Cobban, "Think Again: International Courts," Foreign Policy 153 (2006), pp. 22-28; Jack Snyder and Leslie Vinjamuri, "Trials and Errors: Principle and Pragmatism in Strategies of International Justice," International Security 28, no. 3 (2003/2004), pp. 5-44; and Marlene Spoerri and Annette Freyberg-Inan, "From Prosecution to Persecution: Perceptions of the ICTY in Serbian Domestic Politics," Journal of International Relations and Development 11, no. 4 (2008), pp. 350-84.

${ }^{2}$ Rome Statute of the International Criminal Court, "Preamble," p. 1.

${ }^{3}$ See Antony Duff, "Legal Punishment," in Edward N. Zalta, ed., Stanford Encyclopedia of Philosophy (2013), sections 3 and 4 on "pure" vs. "limited" consequentialism.

${ }^{4}$ See, for worries about the deterrent capacity of international courts, Robert Sloane, "The Expressive Capacity of International Punishment," Stanford Journal of International Law 43 (2007), pp. 71-75; Mark Drumbl, Atrocity, Punishment, and International Law (New York: Cambridge University Press, 2007), pp. 169-73; Kenneth A. Rodman, "Darfur and the Limits of Legal Deterrence," Human Rights Quarterly 30, no 3 (2008), section II. For a seminal critique of deterrence as a justification for punishment, see Jeffrie G. Murphy, "Marxism and Retribution," Philosophy \& Public Affairs 2, no. 3 (1973), pp. 218-21.

5 As elaborated by Sloane in "The Expressive Capacity of International Punishment," pp. 71-73.

${ }^{6}$ As suggested by Martti Koskenniemi, "Between Impunity and Show Trials," in J. A. Frowein and R. Wolfrum, Max Planck Yearbook of United Nations Law 6, no.1 (2002), p. 8.

7 Sloane, "The Expressive Capacity of International Punishment," p. 73.

${ }^{8}$ Retributivist theories range from strong (punishment is required) to weak (punishment is permissible). For a good overview, see Alec Walen, "Retributive Justice," in Edward N. Zalta, ed., Stanford Encyclopedia of Philosophy (2014), section 3, plato.stanford.edu/entries/justice-retributive/.

${ }^{9}$ Hannah Arendt's phrase, quoted in Gary Jonathan Bass, Stay the Hand of Vengeance (Princeton: Princeton University Press, 2000), p. 13.

${ }^{10}$ Kant, although a defender of the death penalty, seems to think that some punishments go against human dignity when he writes that "there can be disgraceful punishments that dishonor humanity itself" and these "make the spectator blush with shame at belonging to the species that can be treated this way." Immanuel Kant, The Metaphysics of Morals (Cambridge: Cambridge University Press, 1996), p. 210. For an excellent discussion of how the deontological commitments of retributivism inform the limits on punishment, see Aaron Fichtelberg, "Crimes Beyond Justice," Criminal Justice Ethics 24, no. 1 (2005), pp. 31-46.

${ }^{11}$ For a defense of the compatibility of retributivism and capital punishment, see Jeffrey Reiman, "Justice, Civilization and Death Penalty," Philosophy \& Public Affairs 14, no. 2 (1985), pp. 114-48.

${ }^{12}$ Cass Sunstein, "On the Expressive Function of Law," University of Pennsylvania Law Review 144 (1996), p. 2051.

${ }^{13}$ See Duff, "Legal Punishment," section 6, for a good overview of communicative and educational theories.

${ }^{14}$ Patricia Funk, "Is There an Expressive Function of Law?" American Law and Economics Review 9, no. 1 (2007), p. 139.

15 Sunstein, "On the Expressive Function of Law," p. 2021.

${ }^{16}$ For some this is the main kind of expression; see, for example, Duffs communicative theory of punishment, which justifies trial and punishment because it engages "the defendant in a communicative 
enterprise." Antony Duff, "Authority and Responsibility in International Criminal Law," in Samantha Besson and John Tasioulas, eds., The Philosophy of International Law (New York: Oxford University Press, 2010), p. 593.

17 See Thomas Scanlon, The Difficulty of Tolerance (Cambridge: Cambridge University Press, 2003), p. 223.

18 Judith Shklar and, more recently, Drumbl explicitly see this as a reason why international criminal courts are worthwhile. Judith Shklar, Legalism (Cambridge, Mass.: Harvard University Press, 1964), at p. 169; Drumbl, Atrocity, Punishment, and International Law, p. 174.

19 Drumbl, Atrocity, Punishment, and International Law, p. 175. Other scholars that apply expressivism to international criminal courts include Diane Marie Amann, "Group Mentality, Expressivism, and Genocide," International Criminal Law Review 2, no. 2 (2002), pp. 93-143; Mirjan Damaska, "What is the Point of International Criminal Justice?" Chicago-Kent Law Review 83 (2008), pp. 329-68; Bill Wringe, "Why Punish War Crimes?" Law and Philosophy 25, no. 2 (2006), pp. 159-91; and Sloane, "The Expressive Capacity of International Punishment."

${ }^{20}$ Empirical studies by, for instance, Orentlicher, Ivković and Hagan, and Nettelfield examine precisely this question and find some support, but they do not relate their findings to a normative theory such as expressivism. Sanja Kutnjak Ivković and John Hagan, Reclaiming Justice: The International Tribunal for the Former Yugoslavia and Local Courts (New York: Oxford University Press, 2011); Diane Orentlicher, Shrinking the Space of Denial: The Impact of the ICTY in Serbia (New York: Open Society Institute, 2008); and Lara Nettelfield, Courting Democracy in Bosnia and Herzegovina: The Hague Tribunal's Impact in a Postwar State (Cambridge: Cambridge University Press, 2010).

${ }^{21}$ In the quote cited above, it is left ambiguous what exactly Drumbl means by the "closing act": verdict or punishment. However, the book as a whole, titled Atrocity, Punishment, and International Law, is largely devoted to the expressive value and current defects in practices of sentencing.

22 Joel Feinberg, “The Expressive Function of Punishment," Monist 49, no. 3 (1965), pp. 397-423.

${ }^{23}$ David Luban also notes the greater importance of trials in the international context. David Luban, "Fairness to Rightness: Jurisdiction, Legality, and the Legitimacy of International Criminal Law," in Besson and Tasioulas, The Philosophy of International Law, pp. 569-88.

24 Orentlicher, Shrinking the Space of Denial.

25 Antony Duff, Trials and Punishments (Cambridge: Cambridge University Press, 1991), p. 236.

${ }^{26}$ Duff, "Authority and Responsibility in International Criminal Law."

27 Anthony Skillen, "How to Say Things with Walls," Philosophy 55, no. 214 (1980), p. 512.

28 Ibid., p. 522.

29 As Jon Elster argued, domestic trials are nearly always too harsh or too lenient. Jon Elster, Closing the Books (Cambridge: Cambridge University Press, 2004). This does not mean, of course, that the court should not attune itself as far as possible to the community it is working within and for.

${ }^{30}$ Rome Statute for the International Criminal Court, Article 17.

${ }^{31}$ See, for instance, Marlies Glasius and Tim Meijers, "Constructions of Legitimacy: The Charles Taylor Trial," International Journal of Transitional Justice 6, no. 2 (2012), pp. 246-47; and Tim Meijers and Marlies Glasius, "Expression of Justice or Political Trial?" Human Rights Quarterly 35, no. 3 (2013), pp. $742-45$.

${ }^{32}$ In the context of the ICTY, Orentlicher points out that the trial establishes the truth of some facts beyond reasonable doubt, thus "shrinking the space for denial." Orentlicher, Shrinking the Space of Denial.

33 Koskenniemi, "Between Impunity and Show Trials," p. 35.

${ }^{34}$ Meijers and Glasius, "Expression of Justice or Political Trial?"; and Glasius and Meijers, "Constructions of Legitimacy."

${ }^{35}$ We discuss this incident in Glasius and Meijers, "Constructions of Legitimacy," pp. 246-47.

${ }^{36}$ This approach may also come at some cost. Prosecuting leaderships of those groups generally viewed (and that view themselves) as the victims of the conflict will also undermine the legitimacy of the court in the eyes of some because they are perceived as the good side. Harnessing the court against the accusation of partiality may render it vulnerable to other complaints threatening its expressive potential. We cannot discuss the details of such a trade-off here, but let us note that prosecuting one party merely to preempt complaints about partiality would be objectionable for reasons internal to expressivism. After all, putting defendants through a long trial without reason would send the message that the legal system can be (ab)used to reach political goals.

37 As we can confirm as occasional visitors to trial sessions at the ICC, the ICTY, and the Special Court for Sierra Leone.

${ }^{38}$ This is reflected by some of the respondents in Glasius (2015), who report that their view on the trial was changed when they saw how meticulously it was done (p. 442). Marlies Glasius, "It Sends a 
Message': Liberian Opinion Leader's Responses to the Trial of Charles Taylor," Journal of International Criminal Justice 13, no. 3 (2015), pp. 419-47.

39 Patrick Vinck and Phuong Pham, for instance, found that 90 percent of respondents in the Central African Republic had become aware of the ICC via radio reports. Patrick Vinck and Phuong Pham, "Outreach Evaluation: The International Criminal Court in the Central African Republic," International Journal of Transitional Justice 4, no. 3 (2010), pp. 421-42.

$4^{\circ}$ See, for instance, Jelena Subotic, Hijacked Justice: Dealing with the Past in the Balkans (Ithaca: Cornell University Press, 2009); and Sara Kendall, "UhuRuto' and Other Leviathans: The International Criminal Court and the Kenyan Political Order," African Journal of Legal Studies 7, no. 3 (2014), pp. 399-427.

${ }^{41}$ Phuong Pham et al., Forgotten Voices: A Population-Based Survey of Attitudes About Peace and Justice in Northern Uganda (Berkeley: Human Rights Centre, 2005); Patrick Vinck et al., Living with Fear: A Population-Based Survey on Attitudes About Peace, Justice, and Social Reconstruction in Eastern Democratic Republic of the Congo (Berkeley: Human Rights Centre, 2008); and Vinck and Pham, "Outreach Evaluation: The International Criminal Court in the Central African Republic."

${ }^{42}$ Nettelfield writing about Bosnia in Courting Democracy in Bosnia and Herzegovina, and Orentlicher about Serbia in Shrinking the Space of Denial are more positive in this regard than many other authors, such as the ones quoted in endnote 1 above.

43 This is echoed by Glasius's fieldwork in Liberia (see "It Sends a Message"), in which several respondents point out that although most Liberians do not follow the trial, the more educated and more internationally oriented members of the public seemed to take a keen interest (p. 428). Nettelfield, too, in Courting Democracy in Bosnia and Herzegovina, points out that the elites in Bosnia picked up on some of the court's messages (p. 148).

44 Shklar (in Legalism), for example, thought this would be the principal contribution of the Nuremberg trials (pp. 166-69). "Certainly total re-education of millions was not feasible. The Trial, addressing itself to the political and legal elite, gave that elite a demonstration of the meaning and value of legalistic politics, not only by offering a decent model of a trial, a great legalistic drama, but by presenting evidence in a way that the political elite could not shrug off."

45 Glasius, in "It Sends a Message," reports that the SCSL is widely perceived among Liberian opinion leaders as an American enterprise (pp. 443-44). 